\title{
The Estimation of Water Demand and Alternative Water Resources in Patra Jasa Building Year 2020-2025
}

\author{
Jantiara Eka Nandiasa and Ari Moyo \\ Faculty Of Engineering, Mercu Buana University, Jakarta, Indonesia \\ jantiara@mercubuana.ac.id, arimoyo01@gmail.com
}

\begin{abstract}
The development of the capital city is very rapidly this will cause water demand will continue to increase along with the rate of population growth, all fulfillment of food needs, and activity of the population closely related to the needs of water. This research aims to determine the total number of water needs required by the Patra Jasa building in the years 2020-2025 and to conserve water use and costs with the presence of alternative water sources. This study used the research method of case study approaches with the accumulation of primary data and secondary data, subsequent analysis of the availability and water needs, and replaced with alternative water sources. From the results of this study, the consumption of clean water $63838.5 \mathrm{~m} 3$, non-consumptive water per year $46681 \mathrm{M} 3$ with details of flushing needs $36500 \mathrm{~m} 3$, watering $6351 \mathrm{~m} 3$, and cooling tower $3650 \mathrm{M} 3$. The potential of source researchalternative water sources as in this is a source of rainwater that can be used to meet the daily needs of the building of $879.38 \mathrm{~m} 3 /$ day so that it can cover all the needs of non-consumptive water. FRP tank design used is FRP tank 1200 $\mathrm{m} 3$ with a method of rain supply that can be harvested from the roof of Patra Jasa building is $320973.7 \mathrm{~m} 3 / \mathrm{year}$ and the average requirement is $174.9 \mathrm{~m} 3 /$ day, $5274 \mathrm{~m} 3 / \mathrm{month}, 63838.5 \mathrm{~m} 3 /$ year. Annual water uses savings of 57835.71 m3/year or Rp. 725,880,160.00.
\end{abstract}

Keywords - hydrology, water supplies, alternative water sources.

\section{Introduction}

The development of the region in the capital is very rapid, this will cause water demand will continue to increase as the rate of population growth. All fulfillment of food needs and activities of residents are always closely related to the needs of water. These needs are inevitable, but must be predicted and planned to be well-utilization. The most common thing is the imbalance between availability and water needs. To achieve the balance between the needs and the availability of future water, it is necessary to analyze water needs and efficiency of water use.

According to the [22] Based on Jakarta data in figures 2018 and 2019, which is collected through survey data and data of several units of Jakarta provincial government is obtained information of water that is channeled to the customers. Most of the water was channeled to companies, stores, and industries with a total of 117,089 subscribers in 2016, in 2017 as many as 119,788 subscribers, and in 2018 as many as 122,070 customers. This amount increases annually with a percentage of the value (in million rupiah) that varies in 2016 by 30.22 percent. 2017 of 30.33 percent and 201830.17 percent, the nominal percentage did decline annually but the number of subscribers and their own nominating rate increased.

Identification of the problem is the availability of clean water is not met well due to the increasing number of population, the need for water needed at the Patra Jasa Tahnun Building 2020-2025, an alternative water source as an efficient way to meet Water needs.

The purpose of this research is to determine the projection of water availability for the fulfillment of nonconsumptive water needs at the Patra Jasa Year building 2020 - 2025, to conserve water and cost with an alternative source of water.

\section{Methodelogy}

This research uses a study method with a case study approach, where the method used is a quantitative and analytical descriptive that aims to evaluate the conditions of a certain period as the basis of planning for the Based on the data that has been collected, based on theoretical and empirical analysis, which is then concluded by the results of the analysis. 


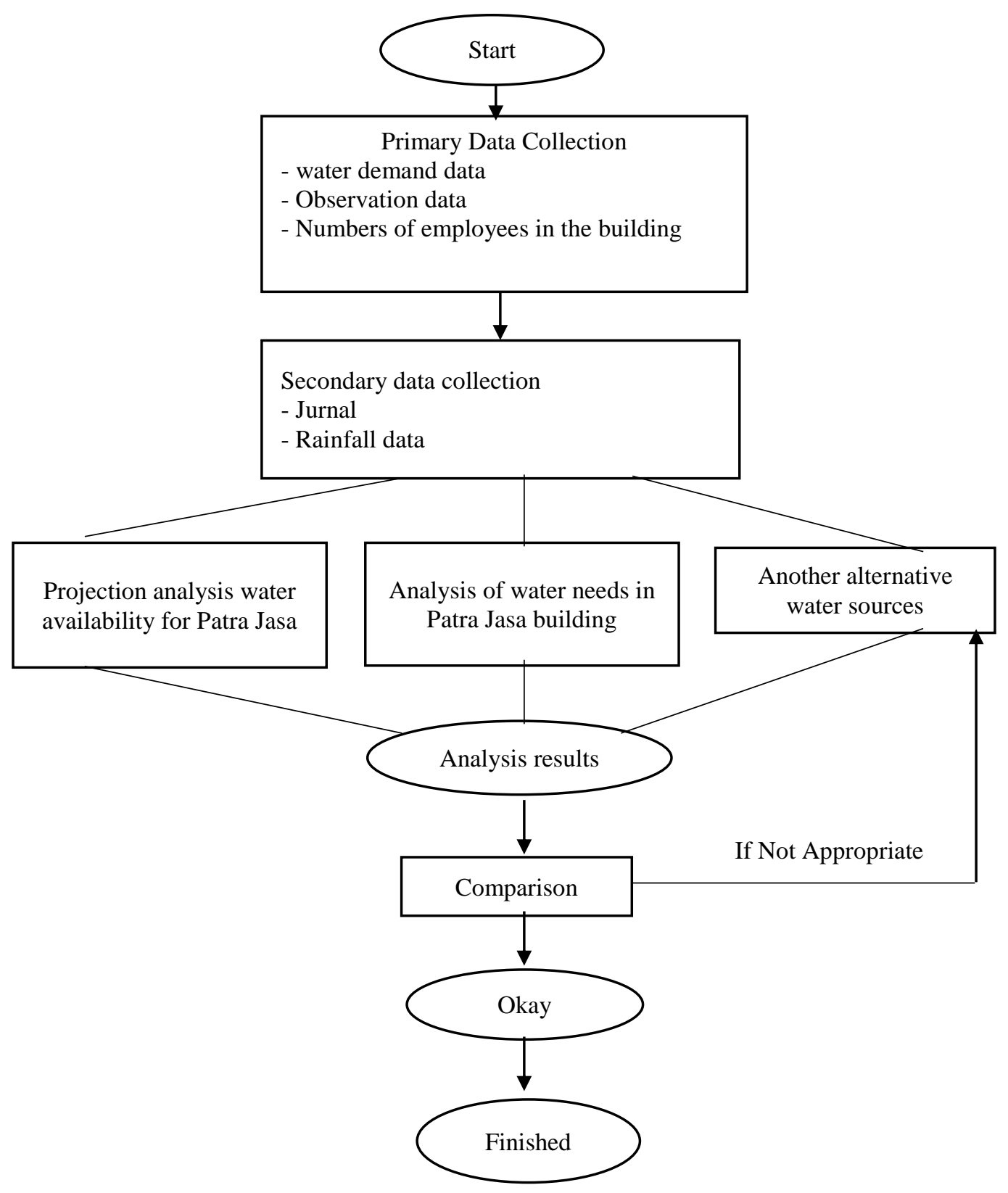

Figure 1. Research Flowchart

\section{Results and Discussion}

The calculation below is the discharge of rainwater for 2 years as follows:

- $\quad$ Coefficient $(C)$ of the Streaming

The flow coefficient is a coefficient whose magnitude depends on the surface condition, slope and material type in the area of rain, it is the roof with concrete material type, which means the coefficient of addressing (C) is 0.95. Can be seen in table II. 2

- $\quad$ Speed Plan (V)

With the requirement the plan speed value $(\mathrm{V})=0.6-1.5 \mathrm{~m} / \mathrm{sec}$, it is taken at $0.6 \mathrm{~m} / \mathrm{sec}$.

- $\quad$ Long rain drains at Patra Jasa Building 


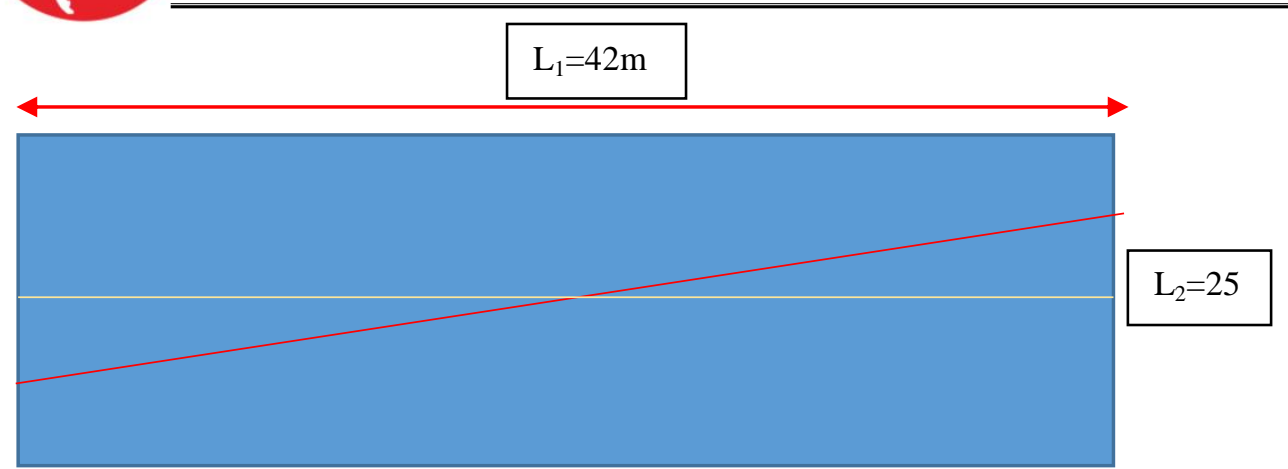

Picture 2. Water drain on Roof in 2 Years

Source : Personal

- $\quad$ Inlet Time $\left(\mathrm{t}_{0}\right)$

The inlet time is calculated by the following formula:

$\mathrm{t}_{0} \quad=0.1 \mathrm{~L}^{0.8} \times \mathrm{S}^{0.3}$

Description:

$\mathrm{S}=$ Slope of rainwater catchment surface, with the requirement of channel slope value of 1-5\%(Taken 1\%)

$\mathrm{L}_{2} \quad=12,5 \mathrm{~m}$

Therefore,

$\mathrm{t}_{0} \quad=0.1\left(\mathrm{~L}_{2}\right)^{0.8} \times(\mathrm{S})^{0.3}$

$=0.1(12,5)^{0.8} \times(0.01)^{0.3}$

$=0.189465$ minutes

- $\quad$ Time of Streaming $\left(\mathrm{t}_{\mathrm{d}}\right)$

$\mathrm{t}_{\mathrm{d}} \quad=\frac{L}{60 \times \mathrm{V}}$

where:

$\mathrm{V} \quad=0.6 \mathrm{~m} / \mathrm{seconds}$

$\mathrm{L} \quad=42 \mathrm{~m}$

Then,

$\mathrm{t}_{\mathrm{d}} \quad=\frac{L}{60 \times \mathrm{V}}$

$=\frac{42}{60 \times 0.6}$

$=1.166667$ minutes

- $\quad$ Time Concentration $\left(\mathrm{t}_{\mathrm{c}}\right)$

Concentration time is the sum of the inlet time with the streaming time, then:

$\mathrm{t}_{\mathrm{c}} \quad=\mathrm{t}_{0}+\mathrm{t}_{\mathrm{d}}$

$=0.189465+1.166667$

$=1.356$ minutes

- $\quad$ Rainfall Catchment Area (A)

The rainy area is the roof area of the building which becomes the object of research, where the rainwater catchment area is $(\mathrm{A})=1050 \mathrm{~m} 2$, can be seen in the following figure.

- $\quad$ Rainfall Intensity (I)

The following are calculations of 2-year rain intensity in this building can be calculated by using the Van Breen method with the following formula:

$\mathrm{I}=\frac{90 \% \times R 24}{4}$

With the calculation of Puh for 2 years, ie:

I $=\frac{90 \% \times R 24}{4}$

$=\frac{90 \% \times 220.38}{4}$

$=49,5855 \mathrm{~mm} / \mathrm{jam}$ 
- $\quad$ Debit (Q) Air Hujan

Rainwater discharge or discharge of rainwater runoff is determined by the area of rain catchment on the roof. Then the discharge of rainwater on the roof is as follows:

$$
\begin{aligned}
\mathrm{Q} & =0.2778 \times \mathrm{C} \times \mathrm{I} \times \mathrm{A} \\
& =0.2778 \times 0.95 \times 220,38 \times 0.000105 \\
& =0.061069 \mathrm{~m}^{3} / \mathrm{seconds}
\end{aligned}
$$

In one day assumed the rainy time is 4 hours, So:

$$
\begin{aligned}
\mathrm{V} & =\mathrm{Q} \times \mathrm{t} \\
& =0.061069 \times(4 \times 3600) \\
& =879,3865 \mathrm{~m}^{3} / \text { days }
\end{aligned}
$$

Thus, the volume of rainwater for 2 years that is accommodated on the reservoir tank to be in a non consumptive clean water is $879.3865 \mathrm{~m} 3 /$ day.

Table 1. Analysis Table of Clean water needs

\begin{tabular}{|c|c|c|c|c|c|}
\hline \multirow{2}{*}{ Period } & \multirow{2}{*}{$\begin{array}{c}\text { Need Consumptive } \\
\text { Clean Water }(\mathrm{m} 3)\end{array}$} & \multicolumn{3}{|c|}{$\begin{array}{c}\text { Non Consumptive clean water needs } \\
(\mathrm{m} 3)\end{array}$} & \multirow{2}{*}{ Total (m3) } \\
\cline { 3 - 5 } & & Flushing & watering & $\begin{array}{l}\text { Cooling } \\
\text { Tower }\end{array}$ & \\
\hline Day & 174.9 & 100 & 17.4 & 10 & 302.30 \\
\hline Week & 1224.3 & 700 & 121.8 & 70 & 2116.10 \\
\hline Month & 5274 & 3000 & 522 & 300 & 9069.00 \\
\hline Year & 63838.5 & 36500 & 6351 & 3650 & 110339.50 \\
\hline
\end{tabular}

Table 2. Clean water Needs Analysis Table

\begin{tabular}{|c|c|c|c|c|c|}
\hline & & \multicolumn{3}{|c|}{ Non - Consumptive water needs years } & Total Cost Of \\
(Rupiah) & $\begin{array}{c}\text { Water Cost Of } \\
\text { Period } \\
\text { Consumptive needs } \\
\text { year (Rp) }\end{array}$ & Flushing & watering & $\begin{array}{c}\text { Cooling } \\
\text { Toner }\end{array}$ & $\begin{array}{c}\text { Non } \\
\text { Consumptive } \\
\text { water year (Rp) }\end{array}$ \\
\cline { 3 - 5 } & 2194995 & 1255000 & 218370 & 125500 & 3793865 \\
\hline Day & 15364965 & 8785000 & 1528590 & 878500 & 26557055 \\
\hline Week & 65849850 & 37650000 & 6551100 & 3765000 & 113815950 \\
\hline Mounth & 801173175 & 458075000 & 79705050 & 45807500 & 1384760725 \\
\hline Year & &
\end{tabular}

Table 3. Supply comparison table with raw water demand

\begin{tabular}{|c|c|c|c|c|}
\hline Month & $\begin{array}{c}\text { Main Rainfall 90\% } \\
\text { (mm/Month) }\end{array}$ & $\begin{array}{c}\text { Rainwater } \\
\text { Availability Volume ( } \\
\text { m3/Month) }\end{array}$ & $\begin{array}{c}\text { Raw water } \\
\text { Needs } \\
\text { (m3/Month) }\end{array}$ & $\begin{array}{c}\text { Raw Water Demand } \\
\text { 10\% of the total } \\
\text { (m3/ Month) }\end{array}$ \\
\hline January & 773,2 & 771267 & 4753 & 475,3 \\
\hline February & 767,8 & 765880,5 & 4753 & 475,3 \\
\hline March & 28,8 & 28728 & 4753 & 475,3 \\
\hline April & 35,9 & 35810,25 & 4753 & 475,3 \\
\hline May & 9,2 & 9177 & 4753 & 475,3 \\
\hline June & 6,3 & 6284,25 & 4753 & 475,3 \\
\hline July & 2231 & 2225422,5 & 4753 & 475,3 \\
\hline August & 20,5 & 20448,75 & 4753 & 475,3 \\
\hline September & 1286,6 & 1283383,5 & 4753 & 475,3 \\
\hline October & 1006,2 & 1003684,5 & 4753 & 475,3 \\
\hline November & 576,4 & 574959 & 4753 & 475,3 \\
\hline December & 109,1 & 108827,25 & 4753 & 475,3 \\
\hline
\end{tabular}


Water Tank Calculations

According to the [16] Based on the comparison between rainwater supply and the demand of Vsuplay raw water < Vdemand so that rainwater supply is insufficient for the overall needs of the average raw water of the building occupants. So calculation of tank Volume based on the supply of securities in January, February, July, September, October, November that tends to supply high rainwater as in table 4.22 with a magnitude of 773.2 , 767.8, 2231, 1286.6, 1006.2, $576.4 \mathrm{~m} 3 /$ month.

VTank $=\frac{\text { Vrainy season supply }}{n}$

$$
\begin{aligned}
& =\frac{773,2+767,8+2231+1286,6+1006,2+576,4}{6} \\
& =1106.866667 \mathrm{~m}^{3} \approx 1200 \mathrm{~m}^{3}
\end{aligned}
$$

\begin{tabular}{|c|c|c|c|c|c|c|c|}
\hline \multirow[b]{2}{*}{ Month } & \multirow{2}{*}{$\begin{array}{l}\text { Supplay } \\
\text { (m3) }\end{array}$} & \multicolumn{3}{|c|}{ First Year } & \multicolumn{3}{|c|}{ Second year } \\
\hline & & $\begin{array}{l}\text { First } \\
(\mathrm{m} 3)\end{array}$ & $\begin{array}{c}\text { Demand } \\
(\mathrm{m} 3)\end{array}$ & $\begin{array}{l}\text { Last } \\
\text { (m3) }\end{array}$ & $\begin{array}{l}\text { First } \\
(\mathrm{m} 3)\end{array}$ & $\begin{array}{c}\text { Demand } \\
(\mathrm{m} 3)\end{array}$ & $\begin{array}{l}\text { Last } \\
(\mathrm{m} 3) \\
\end{array}$ \\
\hline January & 773,2 & & 475,3 & 297,90 & 833,8 & 475,3 & 1131,7 \\
\hline February & 767,8 & 297,90 & 475,3 & 590,40 & 1131,7 & 475,3 & 1200 \\
\hline March & 28,8 & 590,4 & 475,3 & 143,90 & 1200 & 475,3 & 753,5 \\
\hline April & 35,9 & 144 & 475,3 & 0 & 753,5 & 475,3 & 314,1 \\
\hline May & 9,2 & 0 & 475,3 & 0 & 314,1 & 475,3 & 0 \\
\hline Juny & 6,3 & 0 & 475,3 & 0 & 0 & 475,3 & 0 \\
\hline July & 2231 & 0 & 475,3 & 1200 & 0 & 475,3 & 1200 \\
\hline August & 20,5 & 1200 & 475,3 & 745,2 & 1200 & 475,3 & 745,2 \\
\hline September & 1286,6 & 745,2 & 475,3 & 1200 & 745,2 & 475,3 & 1200 \\
\hline October & 1006,2 & 1200 & 475,3 & 1200 & 1200 & 475,3 & 1200 \\
\hline November & 576,4 & 1200 & 475,3 & 1200 & 1200 & 475,3 & 1200 \\
\hline December & 109,1 & 1200 & 475,3 & 833,8 & 1200 & 475,3 & 833,8 \\
\hline
\end{tabular}

Table 4. Water Balance Table

Here is a chart of water balance

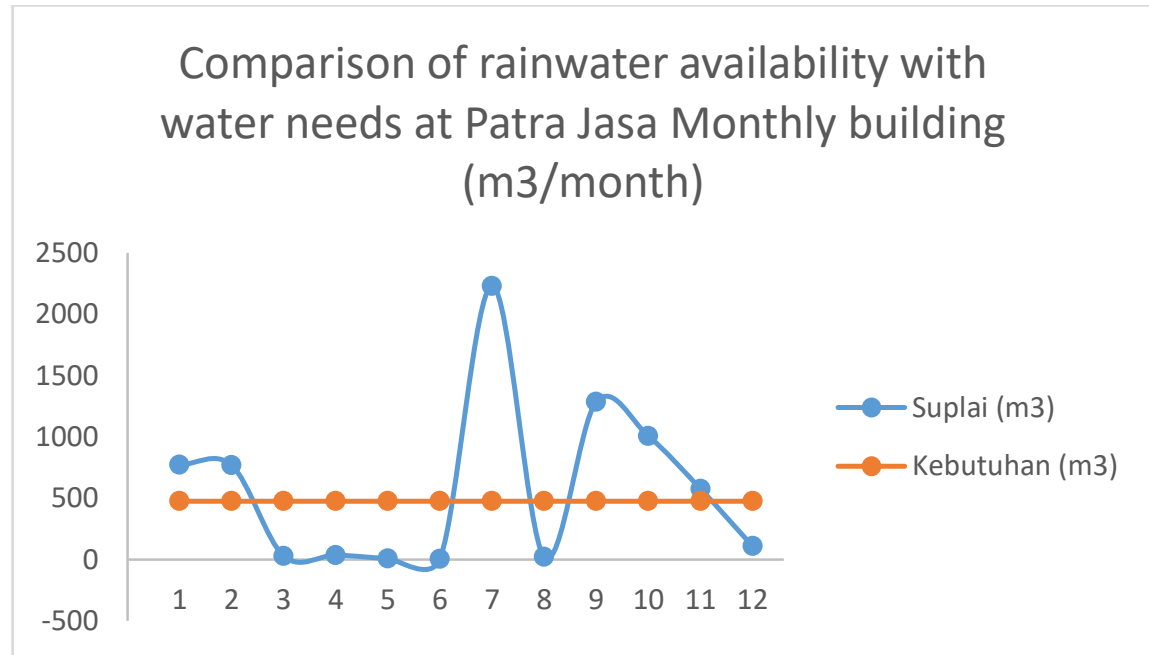

Figure 3. Comparison of rainwater availabitlity with water needs 


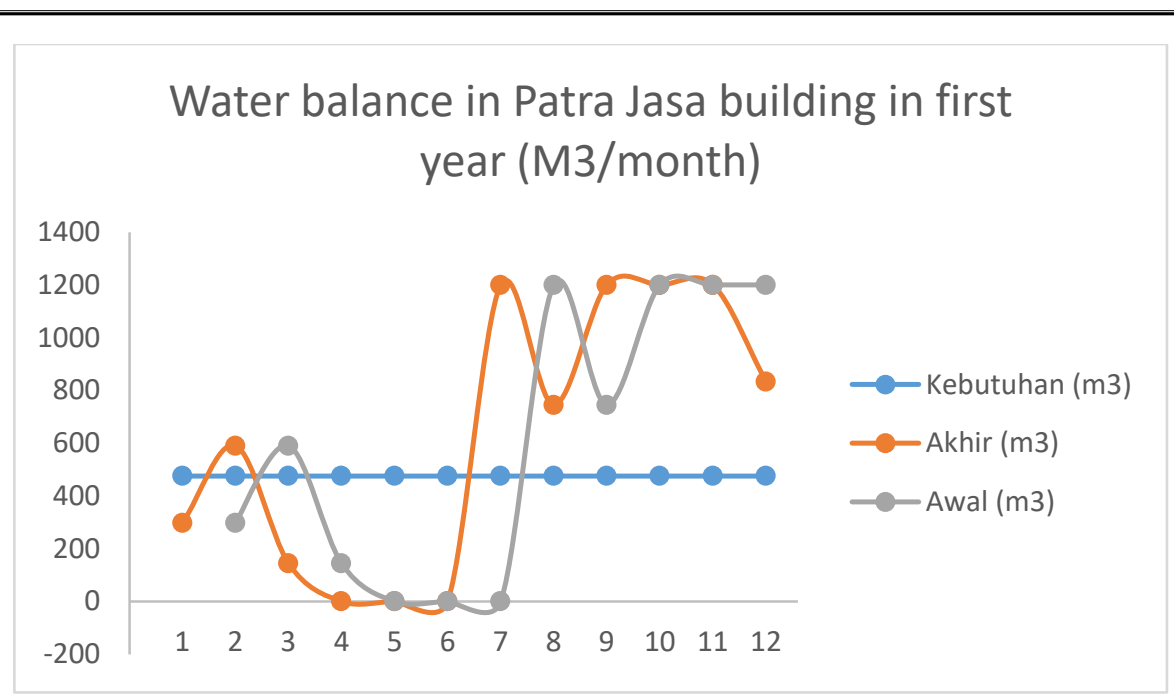

Figure 4. Water balance in Patra Jasa Building in First Year

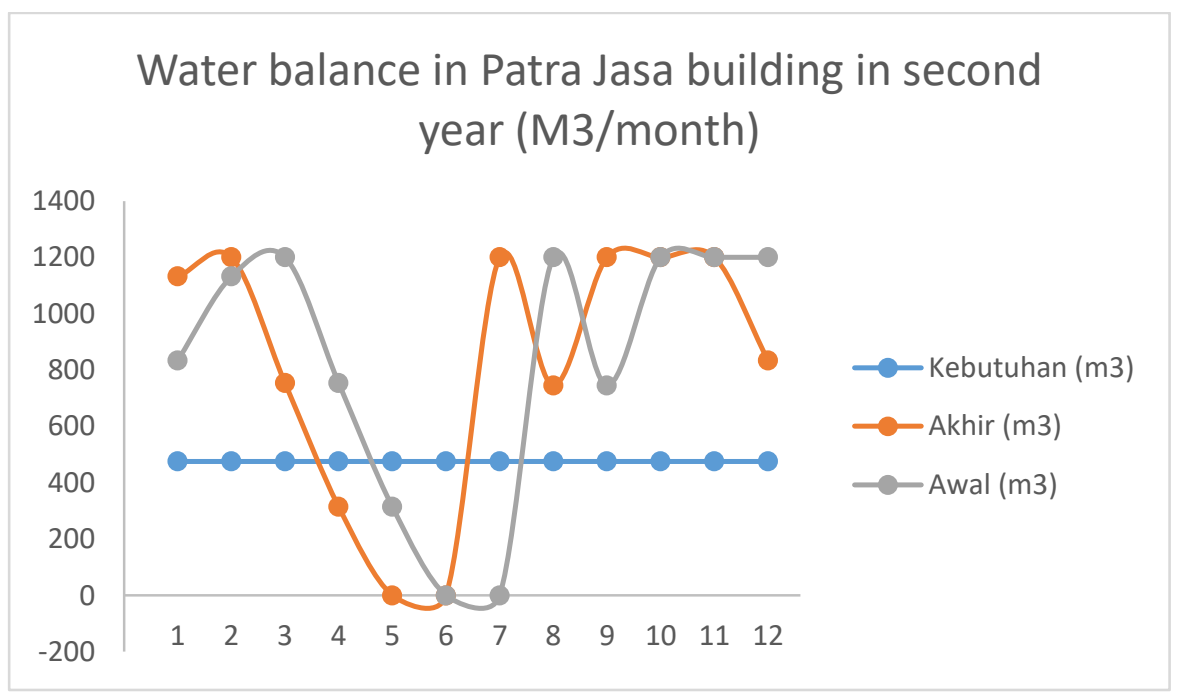

Figure 5. Water Balance

Source: Calculation result

According to the [23] In the first year at the end of December FRP tank still leave water as much as $833.8 \mathrm{~m} 3$ of rain water. So that the remaining water is used for the next year with the same calculations. The first year there is excess of rainwater because the tank capacity is insufficient to accommodate the discharge of rainwater in the tank because it is only able to fulfill a small need. The excess water rain occurs in September, October, November with a magnitude of $355.9 \mathrm{m3}, 886.6 \mathrm{~m} 3,987.7 \mathrm{~m} 3$. Rainwater while the vacuum tank water occurs in May and June.

From the water balance table above the total supply of rainwater that can be accommodated in one year.

Availability of rainwater utilized : Discharge Rainwater x 365

$$
\begin{aligned}
& : 879,38 \times 365 \\
& : 320.973,7 \mathrm{~m}^{3} / \text { tahun }
\end{aligned}
$$

Water Saving PDAM $\quad: \frac{320.973,7}{57.835,71} \times 100 \%$

: 5,5\% dari total kebutuhan air baku penghuni Gedung.

Water Saving when compared to PDAM acquired

$$
\text { : } 57.835,71 \mathrm{~m}^{3} / \text { years x Rp 12550,00 }
$$


These savings do not include electrical financing, pipeline maintenance and maintenance of water pumps.

\section{Conclusion}

1) The potential of this research on the availability of water from alternative water sources such as in this case is a source of rain water that can be used to meet the daily needs of development of $879.38 \mathrm{~m} 3 /$ day so it can cover all the needs of non consumptive water.

2) Based on the analysis of the research needs of consumptive and non- consumptive water is:

a. Consumptive Clean water Year $63838.5 \mathrm{~m}^{3}$.

b. Non Consumptive clean water years $46681 \mathrm{~m}^{3}$ with details needs flushing $36500 \mathrm{~m}^{3}$, Watering $6351 \mathrm{~m}^{3}$, and Cooling Tower $3650 \mathrm{~m}^{3}$.

3) FRP tank design that used is FRP tank $1200 \mathrm{~m} 3$ with a method of rain supply that can be harvested from the roof of Patra Jasa building is $320973.7 \mathrm{~m} 3 /$ year and the average requirement is $174.9 \mathrm{~m} 3 /$ day, $5274 \mathrm{~m} 3 / \mathrm{month}$, $63838.5 \mathrm{~m} 3 /$ year. Annual water use savings of 57,835.71 m3/year or Rp. 725,880,160.00.

\section{Reference}

(1) H.R Lagu, A. M., Amansyah, M., \& Mubarak , F. (2015). Public Health Science Journal. Gambaran Penyediaan Air Bersih PDAM Kota Makassar Tahun 2015.

(2) L. Kawet, H. K., \& Halim, F. (2016). Jurnal Sipil Statik. Perencanaan Sistem Jaringan Distribusi Air Bersih Di Kelurahan Pangolombian Kecamatan Tomohon Selatan.

(3) Lubis, Z., \& Affandi, N. A. (2014). Kebutuhan Air Bersih Di Kecamatan Glagah Kabupaten Lamongan .

(4) Nachshon, U., Netzer, L., \& Livshitz, Y. (2016). Sustainable Cities and Society. Land Cover Properties and Rain Water Harvesting in Urban Environments, 398 - 406.

(5) Nelwan, C., Kekenusa, J., \& Langi, Y. (2013). Jurnal ilmiah sains. Optimalisasi Pendistribusian Air Dengan Menggunakan Metode Least Cust Dan Metode Modified Distribution.

(6) Nugroho, S., Febriamansyah, R., Ekaputra, E. G., \& Gunawan, D. (2019). Jurnal Sumber Daya Air. Simulasi Kebutuhan Air Untuk Tanaman Padi Pada Skenario Perubahan Iklim Didaerah Aliran Sungai Lembang Sumani.

(7) Nurrohman, F., Eka. P, S. W., Sangkawati, S., \& Sugiyanto. (2015). Jurnal Karya Teknik Sipil. Perencanaan Panen Air Hujan Sebagai Sumber Air Alternatif pada Kampus Universitas Diponegoro, 283 - 292.

(8) Rosmin, N., Jauhari, A. S., Mustaamal, A. H., Husin, F., \& Hassan, M. Y. (2015). Sacient Direct. Experimental study for the single- Stage and Double-Stage Two-Bladed Savonius Micro- Sized Turbine for Rain Water Harvesting (RWH) System, 274 - 281.

(9) Silvia, C. S., \& Safriani, M. (2018). Journal teknik sipil fakultas teknik sipil Universitas Teuku Umar. Analisis Potensi Pemanenan Air Hujan Dengan Teknik Rainwater Harvesting untuk kebutuhan domestik, 62 - 77.

(10) Sumarjo, J., Arbi, A. A., \& Dirja, I. (2017). Jurnal Teknologi. Analisis Dan Perencanaan Kebutuhan Pompa Untuk Memenuhi Kebutuhan Air Bersih PDAM Tirta Tarum Kerawang Cabang Teluk Jambe Sepuluh Tahun Yang Akan Datang.

(11) Susilo, J. J., Dermawan, V., \& Hendrawan, A. P. (2017). Studi Perencanaan Penyediaan Air Bersih Padal11 Gedung Bertingkat Tunjangan Plasa VI Kota Surabaya.

(12) Venusia, A., Carlo, N., \& Warman, H. (2012). Analisis Ketersediaan Dan Kebutuhan Air Baku Di Kota Sungai Penuh.

(13) Wahyuni, A., \& Junianto. (2017). Analisis Kebutuhan Air Bersih Kota Batam Pada Tahun 2025.

(14) Wostl, C. P., Kabat, P., \& Moltgen, J. (n.d.). Groundwater Protections in Urban Areas Incorporating Adaptive Groundwater Monitoring And management - Reconcilitaion of Water Engineering Measures Along Rivers. 
(15) Yulistyorini, A. (2011). Teknologi dan kejuruan. Pemamenan Air Hujan sebagai Alternatif Pengelolaan Sumber Daya Air Di Perkotaan, 105 - 114.

(16) Ahmad Zaki, 2008, Analisa Pemanfaatan Rain Barrel sebagai Alternatif Penyediaan Sumber Air di Fakultas Matematikadan Ilmu Pengetahuan Alam Universitas Indonesia,Skripsi, FT. UI, Depok.

(17) Bambang Triatmodjo, 2014, Hidrologi Terapan, Cetakan Ke empat, Beta Offset, Yogyakarta.

(18) Badan Standarisasi Nasional, SNI 03-7065-2005 tentang Tata Cara Perencanaan Sistem Plumbing, Indonesia

(19) Permen PU, 2009, Modul Penampungan Air Hujan, Kementrian Pekerjaan Umum, Indonesia

(20) Suripin, 2004, Sistem Drainase Perkotaan yang Berkelanjutan.Andi Offset, Yogyakarta

(21) Tri Yayuk Susana, 2012, Analisa Pemanfaatan Potensi Air Hujan dengan Menggunakan Cistern sebagai Alternatif Sumber Air pertamanan pada Gedung Perkantoran Bank Indonesia, Skripsi, FT. UI, Depok.

(22) Jakarta dalam angka 2018 dan 2019. Jakarta, BPS DKI.

(23) Maharjono, S., Qomariyah, S., \& Koosdaryani . (2017). Analisis Dimensi Tangki PAH Guna Pemanfaatan Air Hujan sebagai Sumber Air Cadangan Untuk Bangunan Rusunawa . e- jurnal Matriks Teknik Sipil, 258 264.

\section{Biographies}

Ari Moyo is a student from Mercu Buana University in Bekasi with a Civil Engineering Study program. Before majoring in civil engineering, at the previous level namely high school, with a major in Natural Sciences at a private school in Jakarta, Bina Dharma. The author graduated from high school in 2016 then immediately continued his studies at Mercu Buana University in 2016. During his lectures the writer was active in various campus events such as the committee of the creative evening event, the Fun Bike Committee, the Cultural seminar committee. For activeness in the department, namely as Deputy Chair of Civil Engineering in 2018-209, as chair of Civil Engineering in 2019-2020, as Chair of the 2019 Civil Expo General, as chair of the national transportation seminar, Chair of public lecture. in the lecture process the authors do work as a Surveyor in a consultant. 